\section{SCHISTURA NILGIRIENSIS (MENON) IN SHARAVATHI RIVER BASIN, WESTERN GHATS, KARNATAKA}

\section{S. Ali, K.V. Gururaja and T.V. Ramachandra*}

Energy and Wetlands Research Group, Centre for Ecological Sciences, Indian Institute of Science, Bangalore, Karnataka 570012, India

Email: cestvr@ces.iisc.ernet.in * Corresponding author

web supplement

The Western Ghats is one of the hottest hotspots of biodiversity (Myers et al., 2000) endowed with rare, endemic and threatened species of flora and fauna. Freshwater fishes form a major endemic vertebrate group in the Western Ghats after amphibians and reptiles (Gururaja, 2002). India reports 930 species of fresh water fish (Rema Devi, 2003) and 288 are from the Western Ghats. Of these 118 species are endemic to the Western Ghats and Sri Lankan region (Dahanukar et al., 2004). This write up reports the range extension of Schistura nilgiriensis (earlier Nemacheilus nilgiriensis, Jayaram, 1999) from one of the west flowing rivers in the Western Ghats (Sharavathi river $13-15^{\circ} \mathrm{N}$ $\left.\& 74-76^{0} \mathrm{E}\right)$.

\section{Diagnosis}

Schistura nilgiriensis, a small-sized, Endangered (Molur \& Walker, 1998) and endemic fresh water fish of Western Ghats belongs to family Balitoridae (Image $1^{\mathrm{w}}$ ). Five specimens were collected from a first order perennial stream of river Sharavathi at Niluvase $\left(13^{\circ} 44^{\prime} 18^{\prime \prime} \mathrm{N} \& 7^{\circ} 06^{\prime} 30^{\prime \prime} \mathrm{E}, 692 \mathrm{~m}\right)$, Thirthahalli taluk, Shimoga district, Karnataka (Fig. 1) on 6 November 2003 at 18:30hr.

Since water was very shallow (Mean: $6.69 \mathrm{~cm}$, Range: $1.1-10.5 \mathrm{~cm}$ ) fishes were collected by dragging a $30 \times 30 \mathrm{~cm}$ cloth. The stream had rocky bottom, with meager flow. Width of the stream with flow ranged from $0.6-4.5 \mathrm{~m}$ and water temperature was $23^{\circ} \mathrm{C}$. One of the preserved specimen was deposited at Zoological Survey of India (Southern Regional Station, Chennai) on 9 December 2003 (Reg. No. F-7594 SRS/ZSI), and the remaining four are deposited at the Centre for Ecological Sciences field station, at Kumta, Karnataka.

\section{Characters}

Total length is $48.18 \pm 3.5 \mathrm{~mm}$ (range: $42.3-51.1$ ), with uniform depth (Table 1). Barbules are well developed, thread like, six in number, four on the anterior and two on margins of the mouth. Body has 11-13 light brown bands with thin cream coloured interspaces. Lateral line is incomplete, extended till the tip of pectoral fin. Bright red colouration on the anal and dorsal fins was noticed. This colouration gets paler towards the margin. Menon (1999) describes of pelvic fins not reaching the anal opening, however collected specimen have pelvic fins reaching the anal opening. district, Tamil Nadu. Easa and Shaji (1997) recorded this species from Nilgiri Biosphere Reserve $\left(10^{\circ} 45^{\prime}-12^{\circ} 05^{\prime} \mathrm{N} \& 76^{0} 10^{\prime}-77^{0} 10^{\prime} \mathrm{E}\right)$. An earlier study (Shaji et al., 1995) reported S. nilgiriensis from

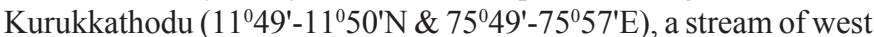
flowing river Uruttipuzha in Aralam Wildlife Sanctuary, Kerala. All these earlier reports were restricted to the southern Western Ghats within $10-12^{\circ} \mathrm{N} \& 74-77^{\circ} \mathrm{E}$. The aerial distance calculated (using MapInfo Version 6.0 GIS software) between the new reports from Niluvase to Kurukkathodu is approximately $225 \mathrm{~km}$ north-west and over $300 \mathrm{~km}$ north-west of Pykara dam.

Schistura nilgiriensis was collected from the south-western part of the Sharavathi river basin which is rich with evergreen to semi-evergreen forests (tree species include Mastixia arborea, Ventilago maderaspatana, Aglaia sp. and Agrostistachys indica). Stream flow monitoring of 28 months show perennial water in the streams in this part (western side least disturbed) compared to the eastern part of the river basin.

This highlights the ecological sensitivity and richness of the region. Presence of $S$. nilgiriensis in the Sharavathi river basin (Karnataka) is a range extension in west flowing river, central Western Ghats

\section{REFERENCES}

Dahanukar, N., R. Raut, and A. Bhat (2004). Distribution, endemism and threat status of freshwater fishes in the Western Ghats of India. Journal of Biogeography 31: 123-136.

Easa, P.S. and C.P. Shaji (1997). Fresh water Fish diversity in Kerala part of the Nilgiri Biosphere Reserve. Current Science 73(2): 180-182. Gururaja, K.V. (2002). Effect of habitat fragmentation on distribution and ecology of anuran in some parts of central Western Ghats. Ph.D. thesis, Kuvempu University.

Jayaram, K.C. (1999). The freshwater fishes of the Indian region. Narendra Publishing House, New Delhi, India, 551pp.

Menon, A.G.K. (1999). Check list-fresh water fishes of India. Records of Zoological Survey of India, Occasional Paper. No. 175: 234-259.

Molur, S. and S. Walker (1998). Conservation Assessment and Management Plan for Freshwater Fishes of India - Report of the Workshop, Zoo Outreach Organisation, Conservation Breeding Specialist Group, Coimbatore, India.

Myers, N., R.A. Mittermeier, C. Mittermier, G.A.B. Da Fonesca, and J. Kent (2000). Biodiversity hotspots for Conservation Priorities, Nature 403(24): 853-857.

Rema Devi, K. (2003). Fresh water fish diversity, pp. 217-224. In: Natural Aquatic Ecosystems of India, Thematic Biodiversity Strategy and Action Plan. Venkataraman, K. (Ed.), The National Biodiversity Strategy Action Plan, Zoological Survey of India.

Shaji, C.P., P.S. Easa, and S. Chand Basa (1995). Freshwater fish diversity in Aralam Wildlife Sanctuary, Kerala, South India. Journal of the Bombay Natural History Society 92: 360-363.

\section{ACKnOWLedGements}

We acknowledge the financial support from the Ministry of Environment and Forests Government of India and Karnataka Power Corporation Limited, Bangalore. We are grateful to Dr. Rema Devi and Dr. Indra, ZSI, SRS, Chennai for timely help in species identification. We thank Sreekantha for valuable suggestions, and Diwakar K. Mesta and Vishnu D. Mukri for the help during field investigations.

\title{
Special notes
}

Menon (1999) reported S. nilgiriensis from Pykara dam, Nilgiri $\quad{ }^{\text {w }}$ See Image 1 in the web supplement at www.zoosprint.org 


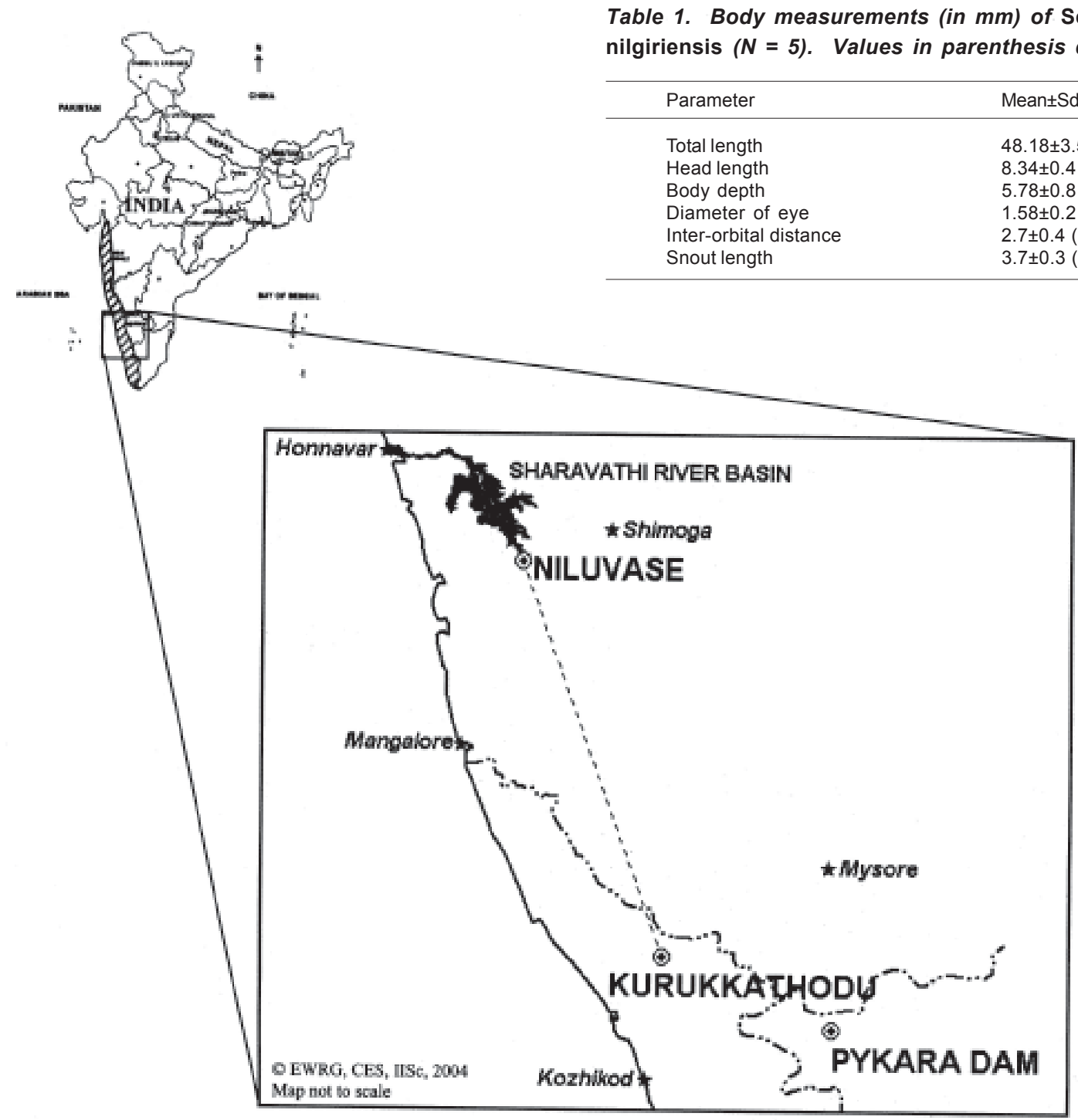

Figure 1. Map of Western Ghats showing new location (Niluvase) and earlier reports

\section{Advertisment \\ FIELD BIOLOGIST FOR WILDLIFE RESEARCH}

Action Oriented Wildlife Conservation Group offers opportunities for Field Biologist to assist with Primary Data Collection, Analysis of Field Data and Report Writing.

Persons who are passionate about wildlife and committed to conservation and good science will be preferred. Experience in analysis of data \& report writing in English is essential. Knowledge of Hindi will be an advantage.

Other skills which will be an advantage in the field are : driving, photography, computers, knowledge of wild animal behavior. Salary will depend on individual's skills. Send your bio data with 1) color photo 2) earlier work reports \& 3) salary expectation by email towsos@vsnl.com

Please enter subject in email as application for Field Biologist. 